\title{
HACIA UNA RETÓRICA DE LA PRESENCIA EN EL EXILIO EN LA DRAMATURGIA DE JORGE DÍAZ Y JERÓNIMO LÓPEZ MOZO
}

\author{
Osvaldo Sandoval \\ Michigan State University, Michigan, EE.UU. \\ sandov46@msu.edu
}

\section{RESUMEN / ABSTRACT}

El presente trabajo analiza la problemática del desarraigo a partir del exilio en las obras teatrales Canción de cuna para un anarquista (2003), de Jorge Díaz, y El olvido está lleno de memoria (2002), de Jerónimo López Mozo. Bajo la idea del regreso real y simbólico en las sociedades posdictadura del Cono Sur y España, el enfrentamiento con la realidad genera un nuevo trauma, el cual se encarga de develar un discurso alternativo que altera un orden social preestablecido. La idea del exilio, de acuerdo a las formulaciones de Edward Said en Reflections on Exile and Other Essays (2000), no solo significa la separación de algo, sino que se traduce en la pérdida de ese algo para siempre. Hablar del exilio, del (auto)exilio o del exiliado no significa restituir la condición de la pérdida, sino más bien se trata de afrontar una realidad sometida al olvido. El exilio en estas obras crea fronteras y barreras que se convierten en un tipo de prisión.

PalABRAS ClaVE: exilio, desarraigo, memoria, trauma, posdictadura.

\section{TOWARDS A RHETORIC OF PRESENCE IN EXILE IN THE DRAMATIC WORK OF JORGE DÍAZ AND JERÓNIMO LÓPEZ MOZO}

This paper analyzes alienation as a consequence of exile in the plays Canción de cuna para un anarquista (2003), by Jorge Díaz, and El olvido está lleno de memoria (2002), by Jerónimo López Mozo. Under the idea of a real and symbolic return in the post-dictatorship societies of the Southern Cone and Spain, the confrontation with reality generates a new trauma, which reveals an alternative discourse that alters a pre-established social order. The idea of exile, based on Edward Said's formulations in Reflections on Exile and Other Essays (2000), not only means the separation of something, but also results in the loss of that something forever. To speak of exile, (auto) exile or the exiled subject does not mean to restore the condition of loss, 
but rather, it faces a reality imposed to oblivion. The exile in these plays creates "borders" and "barriers" that become in a type of imprisonment.

KEYWORDS: exile, alienation, memory, trauma, post-dictatorship.

Después del fervor revolucionario (seamos realistas, pidamos lo imposible); después de las barricadas; después de la represión brutal que nos llenó el cuerpo de cicatrices; después del acomodo, del consenso, de la comida macrobiótica, la cultura "light", la levedad, las tarjetas de crédito e Internet, vivimos ahora sumidos en la perplejidad. No es un estado angustioso, ni siquiera penoso; es, simplemente, una forma de autismo...

(Jorge Díaz, "Palabras, palabras, palabras..." 25)

La reflexión del dramaturgo chileno Jorge Díaz en su Antología de la perplejidad (2003) muestra los efectos de una sociedad orillada cada vez más en la incomunicación. Este aislamiento es una constante en las ocho obras que se presentan en su Antología. Dichas obras se aproximan al desencanto, a la soledad absoluta y compartida, a la nostalgia del abandono y a la idea por encontrar algo que ayude a sus personajes a sobrevivir. Estas características son el producto de procesos sociopolíticos que anulan la posibilidad por encontrar alternativas a los discursos dominantes. Jorge Díaz ha tratado a lo largo de su carrera en Chile y España el problema del desarraigo como una forma de incomunicación. Bajo esta aproximación, Díaz proyecta discursos alternativos que problematizan esa forma de autismo en la sociedad posdictatorial latinoamericana y española.

A través de las voces de los exiliados, la propuesta de mi estudio en las obras teatrales Canción de cuna para un anarquista (2003), de Jorge Díaz, y El olvido está lleno de memoria (2002), del dramaturgo español Jerónimo López Mozo, se basa en la idea del regreso real y simbólico como una forma de desarraigo en las sociedades posdictadura. El enfrentamiento con la realidad genera un nuevo trauma, el cual se encarga de develar un discurso alternativo (de ausencia y presencia) que altera un orden social preestablecido. De esta manera, identifico la palabra desarraigo en el sentido que Díaz le otorga al exilio en sus obras como la "separación de algo" (Cit. en Woodyard 77). Asimismo, parto de la idea del exilio (generalmente por motivos políticos) de 
acuerdo a las reflexiones de Edward Said, en Reflections on Exile and Other Essays (2000), no solo como la separación de algo, sino como la pérdida de ese algo para siempre, ya que "the pathos of exile is in the loss of contact with the solidity and the satisfaction of earth: homecoming is out of the question" (179). En el caso de las obras que analizo, hablar del exilio, del (auto)exilio o del exiliado no significa restituir la condición de la pérdida, sino más bien se trata de afrontar una realidad sometida al olvido. El exilio crea fronteras y barreras y por lo tanto se convierte en otro tipo de prisión. Ahora bien, los discursos de los exiliados rompen con esas barreras y fronteras por medio de sus experiencias (Said 185). Por último, considero en este análisis una aproximación más allá de lo que políticamente constituye el exilio en tanto a la expulsión y el desvanecimiento en su concepción monolítica y homogénea. Los efectos de la desestabilización y el desplazamiento del sujeto exiliado me permiten considerar la multiplicidad, el dinamismo y la intersección a la hora de referirme al exilio, ya que surgen nuevos tipos de separación y pérdida, ya sea interna o externa, que dialogan con las formaciones sociopolíticas y culturales.

La falta de comunicación que propicia el exilio no solo repercute en un orden social, sino también a nivel artístico. A partir del exilio teatral español republicano durante la Guerra Civil Española, aumenta la confluencia entre los dramaturgos, directores y artistas españoles en tierras latinoamericanas. Tras la censura y el silenciamiento que trae consigo el inicio del franquismo, la dramaturgia española exiliada queda propensa al olvido ${ }^{1}$. A través de esta condena a la incomunicación, autores previamente consolidados como Alejandro Casona, Max Aub, María Teresa León, Rafael Alberti, entre otros, se dan a la tarea de denunciar el despojo al que ha sido sometida la sociedad española. Dentro de los artistas y directores, destaca la actriz Margarita Xirgu, que junto a Edmundo Barbero ${ }^{2}$ son de gran influencia en el teatro de Argentina,

\footnotetext{
Para una lista completa de dramaturgos, directores y artistas exiliados, ver "El exilio teatral republicano de 1939" (2002) de Manuel Aznar Soler, pp. 14-29. En su estudio, Soler enfatiza la desvalorización de la literatura dramática exiliada, sobre todo de los jóvenes que se consolidan en Argentina, Chile, Uruguay y México. Este teatro "des-terrado", como lo llama Soler, sufre una condena y censura que prevalece una vez dada la transición democrática. Sobresalen los casos de los dramaturgos José Ricardo Morales y José María Camps, quienes se forjan enteramente en el exilio.

Actor español sobre el cual López Mozo basa su obra.
} 
Chile y Uruguay ${ }^{3}$. Con la aportación de dramaturgos y artistas españoles a la escena latinoamericana, Buenos Aires llega a sustituir a partir de la década de los cuarenta a Madrid y Barcelona como la capital teatral por excelencia (Aznar Soler 12). Más adelante, tras la situación precaria que conlleva a los golpes de estado en el Cono Sur a partir de la segunda mitad del siglo XX, la situación se revierte y se exilian a España figuras de la dramaturgia como Eduardo Pavlovsky, Griselda Gambaro, Diana Raznovich, Susana Torres Molina, entre otros ${ }^{4}$.

De esta forma, el diálogo trasatlántico tanto en la escritura dramática como en el aspecto performativo me conlleva al análisis de la temática que se construye alrededor de la negociación en el exilio. Percibo una transformación que parte de la nostalgia hasta la denuncia de los sistemas fallidos de la transición. Asimismo, la memoria histórica sirve como un elemento en común para no sustentar el olvido. Además del influjo a nivel literario y artístico entre España y el Cono Sur, el quehacer crítico que me ocupa se basa en los discursos que replantean la situación de los exiliados en la época posdictatorial. El énfasis aquí se encuentra en el prefijo "pos-" que implica, en principio, una división entre pasado y presente que podría resolver el sufrimiento del trauma, pero esto no sucede, ya que el término "pos-dictadura" promueve una falsa percepción. El dolor causado por el pasado traumático persiste y existe en el presente ${ }^{5}$. Se trata de una situación que imposibilita la reinserción a la sociedad, ya sea en el espacio sudamericano o español que ocupan los recuerdos de los personajes. Ahora bien, la diferencia en estas obras recae en la idea del regreso físico y simbólico a lo que suele llamarse hogar. En El olvido está lleno de memoria, el protagonista Edmundo Barbero vuelve a España tras cuarenta años de exilio en Sudamérica. Esto no sucede con los personajes de Canción de cuna para un anarquista, los cuales quedan atrapados en un cementerio en Chile, recreando su realidad pasada durante la Guerra Civil Española. La derrota de este regreso real y simbólico de los

\footnotetext{
3 Ver "El exilio español y su influjo en el teatro latinoamericano" de Trinidad Barrera en Las puertas del drama (2000), pp. 44-49.

4 En cuanto al exilio latinoamericano, ver "Para una cartografía teatral del exilio" de Nidia Burgos en Stichomythia (2011), pp. 42-49.

5 Ver el artículo "Por qué hablamos de Postdictadura 1983-2008" de Jorge Dubatti en La revista del CCC (2008), pp. 14-20.
} 
personajes demuestra la continuidad de las políticas del olvido ${ }^{6}$ y los efectos del desarraigo. Dicha continuidad se manifiesta por medio del contexto en las obras que parte en Madrid de 1980 en El olvido está lleno de memoria y se extiende hasta el fin de siglo, alrededor de 1999 en Chile en Canción de cuna para un anarquista.

La escritura de ambas obras coincide con momentos de tensión nacional que marcan un cambio de siglo lleno de irresoluciones y enmascaramientos en cuanto al trauma dictatorial. Las nuevas generaciones siguen cobrando consciencia de lo acontecido, de los crímenes cometidos y de los pactos de silencio de las transiciones. De esta manera, se activa el cuestionamiento de la definición nacional y se busca entonces la redefinición de la autonomía nacional. En Chile, las heridas se reavivan con el caso Pinochet en 1998, su inconclusión y su controvertida llegada en el 2000. Afecta, por otro lado, la pobre respuesta por parte del reporte de los militares que la Mesa de Diálogo había logrado pactar o, más bien dicho, negociar la justicia por la verdad. Tan solo doscientos de los más de mil chilenos todavía desaparecidos fueron mencionados y mucha de la información que se dio fue probada como falsa más adelante; muchos de los cuerpos no se encontraban donde supuestamente los militares decían que estaban. Algunos de los desaparecidos que los militares incluyeron ya habían aparecido (Lazzara 22). Jorge Díaz escribe la versión final de Canción de cuna para un anarquista el 13 de febrero de 2003 en un momento en el que las verdades y la memoria se conjuntan en torno a la lucha contra aquellos fantasmas que siguen rondando la esfera social desde dentro y fuera de la tumba. Díaz intenta darle voz al ser excluido, despojado o desaparecido que a pesar de la muerte de los personajes en la obra, logra recuperar un pasado doloroso. Díaz presenta en su obra una realidad antes negada, pero que sigue siendo base de esfuerzos y luchas para no seguir echando tierra sobre las memorias. Un intento, efectivo o no, es la propuesta del presidente Ricardo Lagos Escobar, No hay mañana sin ayer, en agosto del mismo año, en el que se "reitera" el compromiso de la verdad, justicia y sobre todo reaparición.

6 Me refiero a las políticas del olvido de acuerdo con Tomás Moulián en cuanto a “voltear la página” y "ver hacia el futuro" (Chile actual: anatomía de un mito 2002). Reincide la idea de crear una nación envidiable, o un "tigre económico", como lo llama Moulián. Para lograrlo, es necesario imponer el olvido, puesto que el pasado y sus actores amenazan la destrucción de esa imagen. 
En España también comienza a removerse la memoria histórica a más de veinticinco años de la transición democrática. Las primeras excavaciones en el 2000 no solo exhuman cadáveres sin nombre, sino también se exhuma la memoria que había sido enterrada junto con los cadáveres de los perdedores de la Guerra Civil Española y opositores al régimen franquista. La conmoción que produjeron en la sociedad estos primeros rescates de los cuerpos desaparecidos no solo impacta a nivel nacional, sino también llama la atención a las organizaciones por los derechos humanos y medios de comunicación en el extranjero que obligan al gobierno español a reabrir un diálogo que rescata el olvido e intenta "devolver la identidad a aquellos hombres y mujeres que fueron asesinados y desaparecidos por defender un orden legítimamente establecido" (Silva 111). La sociedad española tuvo que esperar hasta el año 2002 para que el Congreso de los Diputados en España condenara oficialmente de forma unánime el franquismo. López Mozo escribe en ese mismo año la obra incluida en este análisis como una contribución a la explosión de la memoria y a su vez como una crítica de la amnesia que conllevan los años posteriores a la transición, especialmente la década de los ochenta, lo cual marca precisamente uno de los fallos que repercuten veinticinco años más tarde. López Mozo se vale del concepto de la reaparición del cuerpo-cadáver como una forma de visibilizar el cuerpo exiliado y/o desplazado.

Canción de cuna para un anarquista ${ }^{7}$ comienza con el diálogo entre Rosaura y las prótesis de su difunto marido, Epifanio, en un mausoleo en Chile. Junto a estas prótesis, están enterradas también unas gotas para la presión y un guante con el cual Epifanio golpeaba a Rosaura para no dejarle marcas. Irónicamente, Epifanio es incinerado y arrojado a un río tras su muerte y Rosaura decide enterrar en ese mausoleo los objetos que simbolizan el trauma de su pasado. De esta manera, Rosaura llega con la intención de quedarse a vivir ahí, ya que ha sido despojada de su hogar tras no pagar la renta. El regreso simbólico

Estrenada el 11 de junio de 2003 en el Teatro La Comedia en Santiago, Chile, dirigida por Gustavo Meza y con la actuación de Maite Fernández y Fernando Farías. Ha sido representada también por el Teatro El Galpón, dirigida por Sergio Lazzo en el 2008, el Teatro Expresión de la Universidad Arturo Prat en el 2011 y por el grupo Teatro Va, bajo la dirección y actuación de Emilio Hugo Alba en el 2016. Poco se sabe de la recepción de los primeros intentos por llevar a escena esta obra. Sin embargo, la representación teatral del grupo Teatro Va gana cinco premios del Festival Popular de Teatro Entre Ríos, incluyendo mejor obra, mejor actriz, mejor actor, mejor técnica y mejor dirección. 
de Rosaura, así como su realidad inventada, se interrumpe con la aparición de Balbuena, un vagabundo anarquista, atrapado en una realidad de hace sesenta años, que además luchó en el bando republicano durante la Guerra Civil Española. Por medio de recuerdos y sueños fragmentados, tanto Rosaura como Balbuena reconstruyen su pasado real e imaginario. Ambos son víctimas de ambientes propagados por la violencia. A pesar de que Rosaura niega en un principio la realidad de su pasado, la conversación con Balbuena permite el enfrentamiento con la verdad, la cual establece que Rosaura crece regida por la violencia familiar. Balbuena, por su parte, crece huérfano y criado por su abuelo anarquista. Tras su muerte, Balbuena se escapa del orfanato a los 13 años y luego es reclutado en un "sanatorio" para locos que a su vez cumple la función de campo de concentración. Más adelante, lo expulsan del país tras blasfemar, junto con su loro bilingüe, “ ¡Muérete Franco, maldito cabrón! ¡Viva Bakunin y la Anarquía!” (244). Al final, se revierte el papel de la locura y el discurso de Balbuena permite la construcción de un pasado impuesto al olvido. No obstante, el trauma generado del pasado repercute gravemente en el presente de Balbuena y Rosaura, lo cual los conlleva a un suicidio simbólico con dinamita mojada.

Por su parte, El olvido está lleno de memoria 8 presenta el regreso de Edmundo Barbero a Madrid en 1980 después de cuarenta años de exilio en Latinoamérica. Todo comienza con el intento de Julia Ayuso por entrevistar al actor Barbero después de un ensayo de la obra La vida es sueño de Calderón de la Barca. Esta entrevista reactiva la memoria de Barbero y a partir de entonces su pasado comienza a reconstruirse por medio de fotografías, grabaciones y diálogos con la joven periodista. Estos recuerdos marcan tres temporalidades a partir de la persecución, el exilio y el regreso. Conforme avanza la obra, Julia, de familia conservadora, se da cuenta de aquella historia excluida por los discursos oficiales. Es entonces cuando publica el artículo del gran actor Barbero y asimismo pretende escribir un libro de su trayectoria profesional. Cuando comienza a resurgir el pasado, el director teatral Antolín Alvar impone su poder ante Barbero tras separarlo de sus compañeros durante las prácticas y hacerlo optar por abandonar la gira de la representación de $L a$ vida es sueño. Los enfrentamientos entre Alvar y Barbero se incrementan

8 Dirigida por Antonio Malonda y la compañía Teatro Acción Futura. Se estrena en la Sala del Círculo de Bellas Artes en Madrid el 25 de abril de 2003 con una buena aceptación del público, de acuerdo al crítico teatral José Ramón Díaz Sande. 
hacia el final de la obra. Estas discusiones contraponen dos generaciones enfrentadas con realidades distintas. Alvar comenta que mientras Barbero estaba de vacaciones por el "Olimpo del exilio, aquí ya estábamos en el borrón y cuenta nueva" (165). Al ver que todo y nada ha cambiado, Barbero sufre una crisis existencial que culmina con su muerte real en escena. Esta vez, el último personaje que representa es el suyo mismo.

En ambas obras, la presencia del pasado fundamenta las acciones de los personajes. Sin embargo, no se trata de un pasado fijo, sino más bien movible y alternativo. Este pasado altera la imposición de un discurso establecido por las políticas oficiales, tal es el caso de Julia y Alvar. Ambos crecen bajo la historia de los vencedores de la Guerra Civil Española. En el caso de Rosaura, el redescubrimiento de su historia ayuda a deconstruir la idea de un pasado imaginario que ella misma se ha impuesto olvidar. Ahora bien, los conceptos clave en esta instancia son tanto la reevaluación y el diálogo con el pasado, como la redefinición del valor de la verdad. Dichas condiciones crean el espacio del debate o el espacio de lo posmoderno de acuerdo con la poética de Linda Hutcheon ${ }^{9}$. La negociación entre el pasado y el presente, la inclusión de lo excluido, la ausencia en la presencia, la duda y la búsqueda son finalidades que retan la certidumbre, lo absoluto y lo totalitario de los discursos dominantes (Hutcheon 47). Para conseguir estas finalidades, Hutcheon sugiere un acercamiento a la historia "ya dicha" a partir de la parodia y la ironía justamente por su doble función de identificación (presente) y distanciamiento (pasado). La parodia posmoderna usa la memoria histórica y su reflexión para señalar que este tipo de discurso de autorreflexión está inescapablemente atado al discurso social. De esta manera, la parodia ofrece una perspectiva del presente y del pasado, "which allows an artist to speak to a discourse from within it, but without being totally recuperated by it" (Hutcheon 35). La parodia y la ironía en Canción de cuna para un anarquista y El olvido está lleno de memoria sirven como estrategias que develan la fragmentación de los personajes en el antes y después a través de la memoria. Ahora bien, la cuestión radica en examinar lo que la fragmentación intenta

\footnotetext{
Hutcheon declara desde un principio la función contestataria de conceptos tales como discontinuidad, disrupción, dislocación, descentralización, indeterminación y antitotalitarismo. Estos conceptos incorporan precisamente lo que el posmodernismo plantea ( $A$ Poetics of Postmodernism 3).
} 
develar y/o deslegitimar ${ }^{10}$. Por lo tanto, la fragmentación individual y colectiva que surge a partir del exilio en ambas obras pretende mostrar el trauma que genera este desarraigo forzado. Esta acción o cicatriz en el pasado resurge en el presente para presentar lo que antes era impresentable (no digno de presentarse), en el sentido de cualquier expresión artística en Lyotard (The Postmodern Condition 81), o resurge para (re)presentar lo irrepresentable en respuesta a la diferencia estética posmoderna en Hutcheon (A Poetics of Postmodernism 55).

Ahora bien, ¿cómo presenta la dramaturgia dichos espacios del debate en la última década del siglo XX? Lo que el teatro posmoderno agrega a estas características, de acuerdo con Jeanette R. Malkin en Memory-Theater and Postmodern Drama (2002), son la voz y la imagen, en vez de la narrativa y el personaje, enfatizando lo colectivo y lo interactivo en lugar de lo individual y un texto autosuficiente. La imagen del "yo" se fragmenta y se presenta en el escenario como una adaptación o personificación múltiple. A lo largo de El olvido está lleno de memoria, Barbero está en una constante búsqueda de su verdadero "yo", por medio de otros personajes. Esto mismo ocurre en Canción de cuna para un anarquista con Rosaura, a pesar de no ser una actriz de vocación. Es decir, Rosaura actúa un "yo" imaginario al principio; más adelante, con la recuperación del pasado, redescubre su "yo" real. Ambos, Barbero y Rosaura, al enfrentarse con su realidad fragmentada, mueren. El acercamiento de Malkin hacia un teatro de la memoria es definido como un teatro que imita memorias conflictivas, reprimidas o borradas de un pasado compartido. Estas memorias se representan en forma de flashbacks o alucinaciones que se convierten en aberraciones psicológicas. El teatro posmoderno de la memoria involucra una perspectiva desestabilizada. "That connecting context, the thread that ties history and memory to a vision of the future, is precisely what is no longer available in a postmodern world" (Malkin 148). Ahora, el pasado sale a la luz en el escenario con imágenes contradictorias o transformaciones irracionales. Se trata de discursos enfrentados, objetos inexplicables, imágenes que se entrometen o voces entremezcladas. No existe la unidad de la enunciación, no hay cierre, no hay manera fácil de leer $\mathrm{u}$ organizar la sobrecarga discursiva. Las memorias aparecen en escena sin orden, sin dirección y sin coherencia. Al igual que Canción de cuna para un

10 En el sentido de rechazar o cuestionar las grandes narrativas, ver "Delegitimation" en Lyotard, The Postmodern Condition (1979), pp. 37-41. 
anarquista y El olvido está lleno de memoria, las obras teatrales que analiza Malkin marcan el sentido de una relación conflictiva y traumática en relación con el pasado ${ }^{11}$. El diálogo activa la memoria e incita el acto de recordar. No obstante, la forma caótica de representar la memoria y su fusión temática niegan la posibilidad de recuperación o restauración del pasado (Malkin 215).

Las mismas fórmulas en torno a los discursos alternativos de la memoria descentralizan la imposición del olvido y la obsesión por la normalización social en las políticas de la transición democrática en el Cono Sur y España a fines del siglo XX. El teatro posdictadura en ambos lados se encarga de presentar una realidad que se define en términos de ausencia. El énfasis que Beatriz J. Rizk examina en Posmodernismo y teatro en América Latina (2001) en lo que concierne a un teatro posmoderno latinoamericano reincide en la idea de "encontrar esos específicos 'lugares de la memoria' que preserven una identidad, ya de carácter múltiple y pluralista, y le den a la vida un sentido de conservación y sobre todo de continuidad" (67). El acercamiento al posmodernismo en Rizk parte desde "nuestro momento cultural, ya definitivamente plurivalente y globalizado" (133). A diferencia del posmodernismo a principios del siglo XX en Latinoamérica que va en contra de los excesos poéticos del modernismo y de un lenguaje universal, Rizk examina un posmodernismo que se encarga de la integración, tal como lo analiza Hal Foster, cuyo estudio distingue al posmodernismo posestructuralista en comparación y contraste con el posmodernismo neoconservador ${ }^{12}$. El arte posmodernista es un arte que sigue imitando la vida, pero ahora el reflejo es por medio de "espejos cóncavos y convexos... con imágenes que no han sido reflejadas" (Rizk 39). Las realidades se confunden con sus imitaciones justamente por la creación de identidades alternativas que se admiten en la

11 Ver la sección "Horizontal Memory: Lieux de Mémoire", en Malkin, MemoryTheater and Postmodern Drama (2002), pp. 22-24. La lectura del trabajo de Pierre Nora denota esa asociación fragmentada entre la historia y la memoria que con el posmodernismo se desasocian como continuidad y complementación. Es decir, la memoria no es necesariamente una continuación del pasado en el presente. Se trata de que la memoria sea un rasgo de ese pasado para reinterpretar el presente.

12 Ver "(Post)Modern Polemics", en Hal Foster, Recordings: Art, Spectacle, Cultural Politics (1985), pp. 121-138. Los excesos (lo feo, lo grotesco, lo absurdo, lo bello) más que ir en contra de ellos, pasan a ser parte referencial de las "estrategias disruptivas, en calidad de accesorios", para representar (y parodiar) la realidad (Rizk 133). No es un teatro de reacción al modernismo, según Rizk, sino un teatro posmoderno que intenta recuperar, como plantea Hutcheon, lo que el modernismo descarta. 
memoria o en los sueños, como lo presenta Rizk en el análisis de las obras del colombiano Santiago García y el argentino Arístides Vargas. En el caso de la dramaturgia española, el análisis de Candyce C. Leonard y John P. Gabriele integran el papel de la memoria como un referente a "la fragmentación de la realidad y la disolución del ser que caracterizan la época posmoderna... los dramaturgos de la segunda mitad del siglo XX y principios del XXI se sirven de la memoria como convención dramática para representar realidades ambiguas e incoherentes" ("Memoria teatralizada/vida rememorada" 4). Tanto en el Cono Sur como en España, así como la realidad posmoderna, el teatro posdictadura de la memoria se destaca por la experimentación y el implemento metafórico, la ironía, la parodia y la metateatralidad. Estas características se llevan a escena por medio de una negociación entre el texto dramático y la expresión performática ${ }^{13}$. Dicha negociación es necesaria cuando se intentan representar situaciones irrepresentables de un pasado traumático, tales como el proceso de desarraigo. La incorporación de imágenes fotográficas en la representación teatral El olvido está lleno de memoria ${ }^{14}$ o la actuación de Emilio Hugo Alba basada en silencios que hablan y gestos simbólicos en Canción de cuna para un anarquista refuerzan la autorreflexión y por ende, dialogan con la memoria del espectador.

A partir de una aproximación posmoderna en el teatro, vemos que la historia de los exiliados en la sociedades de los vencedores no es digna de contarse. Por esta razón, nadie ha oído hablar del actor Barbero dentro de la obra de López Mozo. Cuando llega al aeropuerto en 1980, Barbero dice, "nadie salió a mi encuentro... Ni mi familia. ¡Mierda! Ni un periodista, ni un fotógrafo..." (187). Asimismo, su incorporación al grupo teatral de Alvar es producto de un favor que le piden. Ahora bien, a más de cinco años de la transición democrática española, la historia de Barbero sigue siendo indigna de presentarse como lo demuestra el rechazo de Alvar a lo largo de la obra y

13 Ver "Entre la ausencia total del texto y el teatro de narración oral", en Rizk, Posmodernismo y teatro en América Latina (2001) pp. 123-30, y "La búsqueda del despojamiento" en López Mozo, RESAD (2001), pp.1-17. Ambos casos tratan el debate en cuanto a la multiplicidad de hacer teatro a fines del siglo XX.

$14 \quad$ Estas imágenes se relacionan con el periodo comprendido entre las elecciones generales de 1931 y 1977. Las imágenes aparecen agrupadas bajo los siguientes epígrafes: "16-2. Elecciones generales", "Triunfo frente popular", "18 julio 1936", "El exilio", "5 de abril de 1939", "40 años de silencio", "20 noviembre 1975", "Regreso de los exiliados" y "15 de julio de 1977". 
tras el intento de impedir que Julia siga indagando en el pasado. La angustia de Barbero radica en ver la indiferencia de una nueva generación incapaz de comprender el dolor de su desarraigo. Hasta el momento, Barbero no ha podido representar ese sentimiento de desolación en escena. Tras esta impotencia de transmisión, la única alternativa de representar lo irrepresentable es por medio de su muerte. Lo mismo ocurre en Canción de cuna para un anarquista con Rosaura y Balbuena. Ambos se encuentran desolados en un Chile fantasmal que, de una manera similar al caso español, practica el olvido tras la dictadura de Pinochet. En este caso, han pasado casi diez años de la transición. Rosaura vive en una fantasía impuesta por ella misma ya que es incapaz de asimilar su realidad. Esto se percibe en la risa amarga que provocan sus comentarios absurdos ${ }^{15}$. Con la ayuda de Balbuena, Rosaura encuentra esas imágenes antes bloqueadas, irrepresentables en su imaginario debido al dolor que le provocan, y por fin acepta su liberación por medio de la muerte. Por otra parte, las memorias de Barbero no presentan una linealidad, sino más bien divagan entre la representación de sus personajes durante la Guerra Civil Española y las posteriores en Sudamérica, en el caso específico de Montevideo. Estas memorias, más allá de las grabaciones y los flashbacks, se presentan con los versos en su papel de Segismundo, cobrando así una doble voz que se entremezcla. Los cambios de temporalidad, por su parte, se denotan en las acotaciones por medio del oscuro sin marcar un regreso definido. Lo mismo pasa con Canción de cuna para un anarquista, pero con la incertidumbre de saber si los recuerdos son reales o inventados como lo hacen con su realidad. En este caso, el autor da libertad absoluta para marcar los cambios de tiempo en la memoria.

En cuanto al efecto del regreso físico y simbólico en las obras, se muestra la idea del desarraigo como manifestación de un trauma que genera el enfrentamiento con la verdad. En primer lugar, el desarraigo en Rosaura y Balbuena en Canción de cuna para un anarquista precede una realidad

15 Es absurdo en relación con "The Absurd Man" en Albert Camus, The Myth of Sisyphus and Other Essays (1991), pp. 65-92. "A world that can be explained even with bad reasons is a familiar world. But, on the other hand, in a universe suddenly divested of illusions and lights, man feels an alien, a stranger. His exile is without remedy since he is deprived of the memory of a lost home or the hope of a promised land. This divorce between man and this life, the actor and his setting, is properly the feeling of absurdity" (75). Camus concluye que el sentimiento o percepción de la absurdidad es una de las causas de la negación de la memoria, que no solo indica incertidumbre, sino además denota la desesperanza. 
física y simbólicamente violentada. El regreso, en este caso, se trata tanto de un retorno al pasado como al presente. Es decir, regresar al pasado significa regresar a la realidad precaria en la que viven ambos personajes. Es una manera de revivir el trauma del pasado que activa un nuevo trauma, especialmente en Rosaura. En base al abandono y el regreso del trauma, a pesar de que una persona sostenga o intente olvidar, el trauma de una manera $\mathrm{u}$ otra regresa y es entonces cuando se experimenta por primera vez. Se trata no tanto de olvidar el pasado doloroso, sino que el olvido no significa que el trauma se supere. Al contrario, puede aparecer latentemente por primera vez. Cathy Caruth declara que el trauma "is always the story of a wound that cries out, that addresses us in the attempt to tell us of a reality or truth that is not otherwise available" (Unclaimed Experience: Trauma, Narrative and History 4). El desarraigo tras el exilio en una primera instancia se extiende hasta el momento de la muerte de Rosaura. Esto se caracteriza por el intento de sobrevivir en la ambigüedad de su realidad; una realidad que bien puede tratase de un mundo fantasmal. Así lo manifiesta Rosaura hacia el final de la obra, "siempre tuve miedo de que yo estuviera muerta y no me diera cuenta. Ayer volví a mirar las lápidas y encontré una con mis dos apellidos y mi nombre. ¿Usted cree que estoy enterrada allí?” (259). Su estado de supervivencia en un Chile posdictadura, en vida o en muerte, se propicia debido a la violencia de su pasado. Rosaura crece bajo una violencia familiar y política. Balbuena vive bajo la represión fascista, el cual sufre "las conexiones en las sienes, el tapón de goma en la boca; los aullidos...Mi cuerpo retorcido que no era mi cuerpo, sino el de un gusano reventado en excrementos, orines y vómitos" (260). Ambos comparten situaciones trágicas tales como los bombardeos en Barcelona en 1938. Por un lado, el poder hegemónico del Estado conlleva al exilio de Balbuena. En el caso de Rosaura, se aúna un poder psicológico individual que provoca su aislamiento. Es decir, el exilio psicológico que conlleva la apropiación de una identidad alterna es una estrategia que se manifiesta desde el principio como una manera de autoimponerse el olvido para bloquear el trauma de su pasado. A pesar de quemar las fotos de su historia como primer intento por olvidar, esta autoimposición fracasa ya sea por sus rodillas que pronostican la lluvia, sus vestidos floreados en tiempos de luto o por los pájaros que tiene en la cabeza. Estas características representan algo fuera de lo común y por ende, no encaja con el resto de la sociedad, lo cual se ejemplifica con la señorita Elvira, exnovia de Epifanio, que siempre va vestida de luto como lo deben hacer las viudas y no con un vestido floreado como el de Rosaura. Lo diferente (lo absurdo) es una manera de recordarle 
a Rosaura la frontera que distingue a los "outsiders", que se traduce en un sentimiento de no pertenecer. Lo que intenta Rosaura es lo que los exiliados consciente o inconscientemente buscan, "an urgent need to reconstitute their broken lives, usually by choosing to see themselves as part of a triumphant ideology or a restored people" (Said 177).

Por su parte, el futuro de Rosaura se reduce a un cementerio, con una maleta con la que puede "ir hasta el fin del mundo. Y el fin del mundo debe parecerse a este lugar" (238). El mausoleo, como símbolo de muerte, es el lugar donde se conjuga el pasado, presente y futuro de Rosaura y Balbuena. Dichas temporalidades asocian la soledad y el desplazamiento producido por el exilio (Said 146). De esta manera, el desarraigo corrompe la estabilidad emocional de estos personajes. Balbuena es un vagabundo atrapado en la historia. Rosaura, por su parte, vive en una realidad alternativa que ahora se integra a la precariedad del vagabundo tras haber sido despojada de su casa. A pesar del regreso a un pasado que ahora pueden recordar juntos, su suicidio simbólico no solo demuestra la imposibilidad de una reinserción social, sino también la pérdida irrecuperable de su identidad. La imposibilidad y la pérdida se ejemplifican a lo largo de la obra con la espera infinita de un simbólico tren ${ }^{16}$ que no llega sino hasta el final, cuando las acotaciones sugieren la muerte de ambos, seguido inmediatamente del telón.

En el caso de Barbero, en El olvido está lleno de memoria, el desarraigo se muestra como un proceso agónico. Al igual que Balbuena y Rosaura en Canción de cuna para un anarquista, Barbero se ve obligado al exilio. Su participación con el Teatro de Arte y Propaganda y de las Guerrillas del Teatro que actuaban en los frentes de guerra lo condenan a la persecución y consecuentemente busca asilo en la embajada de Chile. La degradación de Barbero se agudiza a partir de los recuerdos en su memoria, fotografías y grabaciones para la entrevista del periódico El Independiente. El regreso de los recuerdos, y por ende del trauma, reflejan la angustia al momento del exilio, la añoranza durante su estadía en Latinoamérica y la desilusión cuando intenta regresar por primera vez a mediados de la década de los cincuenta. Este primer rechazo por regresar lo declama de memoria Barbero, tras recibir en el pasado una carta de sus familiares con una nota irónica del periódico

16 Nos remonta a la obra clásica del teatro del absurdo de Samuel Beckett, Esperando $a$ Godot (1952). Es la espera eterna de la esperanza. La ausencia del tren se traduce entonces en la ausencia de la esperanza. 
que dice, "Nos parece bien que, acogiéndose a la generosidad del gobierno, retorne a esta Patria olvidadiza respecto a los desmanes de sus hijos díscolos... supervivientes vergonzantes de su misma cuerda...pediremos que, como a los fantasmas que vuelven al castillo...se le proporcione la paz de los muertos. Amén" $(164)^{17}$. La carta dice, asimismo, que su regreso pone en peligro a su familia. De esta manera, Barbero sufre un doble desarraigo que se recapitula en el antes y después de la dictadura. A pesar de darse el regreso físico a la escena española en 1980, la función de Alvar en tanto alegoría a cualquier dictador como parte de una nueva generación impide que Barbero supere el sentimiento de no pertenencia, tal como Alvar se lo recrimina:

Aquí, soy yo el que manda. ¿Está claro?... ¿No te das cuenta de que más de media España nació cuando tú ya no estabas aquí? ¿Qué nos importan tus chismes? ¿Quién desea escuchar un revoltijo de calamidades y de fanfarrias inventadas? Llegas tarde. El tío de América nos la trae floja. A callar y a trabajar. Es lo que toca (164).

En este caso, la apertura a la democracia y a los valores culturales y artísticos sufren de alguna manera una censura simbólica. Barbero se da cuenta de que su regreso es un regreso nuevamente al encierro, aunado a la comercialización del teatro. El concepto de transición evoca movimiento, que regularmente es una tendencia a la apertura, pero es a la vez un fenómeno simultaneo de encierro $^{18}$. Por esta razón, cuando se deforma el concepto de apertura, la función social del teatro que determina la demanda por un cambio a favor de la sociedad se convierte en una función social favorable a unos pocos, tal es el caso de la compañía que dirige Alvar. Él mismo manifiesta su tiranía sin ningún juicio moral al recriminarle a Barbero su intención de recuperar una ideología perdida.

17 López Mozo utiliza un artículo que en realidad se escribió en La Vanguardia Española en 1949, pero dirigido hacia la actriz Margarita Xirgu.

18 En el artículo "Every Transaction Conjures a New Boundary," en Critical Theory and Performance (2007), Josette Féral deconstruye el significado del movimiento global hacia la apertura en el que se crean interminables zonas de exclusión y aislamiento, así como la creación de nuevas fronteras, ya sean físicas o simbólicas. El contexto social es la causa principal de está doble significación de transición. Es decir, de una manera simbólica, la transición a una apertura, ya sea del estado capital, cultural o artístico, no significa ciertamente una trascendencia al desarrollo de la sociedad. Puede significar de la misma manera una trascendencia aparentemente a favor del desarrollo social, pero de manera controlada, lo cual conlleva a la división o fronteras dentro de una misma nación. 
Otra instancia que problematiza el regreso se da a través de las declamaciones poéticas personificadas de Barbero en el papel de Segismundo de la obra $L a$ vida es sueño. La metateatralidad, al igual que la metaficción histórica, en el sentido de Hutcheon, determina que la ficción no es un espejo de la realidad, ni la reproduce. No obstante, la ficción se ofrece como otro de los discursos en el cual construimos nuestras versiones de la realidad. Ambas finalidades recaen en la construcción de esa realidad y la necesidad de hacerlo. A través de esta metateatralidad, la alegoría al sentido metafísico de la existencia y los espacios simbólicos que existen en ambas obras permiten la comparación y el contraste de mundos distanciados que a su vez se conjuntan. La importancia de la ilusión frente a la realidad, el sentimiento existencial de inferioridad y la privación de la libertad, como le ocurre a Segismundo, son rasgos apropiados por Barbero bajo un exilio ahora infinito. Con la integración y/o apropiación del "otro" (ya sea Segismundo, Clotaldo, el rey Basilio, Jasón, Pipo, Liseo, entre otros) como parte de la búsqueda de la identidad de Barbero, la obra desafía la noción del "yo" integral ${ }^{19}$. Hacia el final de la obra, Barbero desnuda su realidad, agoniza entre sombras y reclama:

Yo tenía que haber vivido en España. No fue posible. ¿Saben que hubo una guerra civil?...Alguien tendría que haberles hablado de ella... ¿Por qué no les han dicho nada? ¿Tal vez porque es algo remoto?... Los recuerdos perduran. Sólo han pasado cuarenta años. ¿O ha habido un pacto de silencio? En esa guerra yo estaba del lado de los que perdieron...El precio que pagué fue poner tierra de por medio (186).

Se trata de un pacto de silencio tan característico de las transiciones democráticas en el último cuarto del siglo XX. Al final, bajo declamaciones trastornadas, Barbero muere y Julia se encarga de decirle a la audiencia, "recuerden que tuvieron el privilegio de verle actuar en el papel más difícil: el suyo" (190). La ironía se presenta con un Barbero que al inicio vive una ilusión más allá del escenario y al final vive una realidad en el escenario. Así, el verdadero papel de Barbero es el papel del exiliado y su incapacidad por superar un regreso auténtico. La ausencia durante su exilio continúa siendo una ausencia

19 En cuanto a este proceso, ver "Identidad y memoria en el exilio", en Alicia Alted, La voz de los vencidos (2005), pp. 391-427. 
en su regreso. Solo tras su muerte, esa ausencia irónicamente se convierte en presencia ${ }^{20}$.

Finalmente, el regreso de Barbero trae consigo la confrontación artística y el valor intrínseco del teatro. Esta confrontación muestra otra parte importante en el proceso de desarraigo, ya que la vida de Barbero se constituye alrededor de la expresión artística. En cuanto a las palabras, Barbero recrimina que no "basta con arrojarlas. Hay que saber dónde van a parar, qué sucede cuando golpean la consciencia de los espectadores. Eso hice. Y, al comprobar los resultados, percibí de nuevo el inmenso poder del lenguaje" (157). De este modo, no sorprende el resultado fallido de Barbero en la representación del rey Basilio. Es decir, no consigue personificarlo, ya que no está dispuesto a perderse en ese laberinto de palabras sin sentido. A través de Barbero, López Mozo, con rasgos autoideológicos, demuestra la importancia que radica en el sentido de las palabras y su función social. Se trata de revalorizar y de alguna manera enlazar el efecto de las palabras en su doble significación, tanto textuales como articuladas. En este aspecto, y de acuerdo con Santiago Trancón en Teoría del teatro (2006), el teatro es uno de los lugares en que "la palabra se libera de las normas sociales y los usos habituales del lenguaje" (151). Los signos sociales, el gestus brechtiano, determinan el comportamiento y la relación con las personas. Estos signos se identifican en las diferentes dimensiones del role-playing con Barbero. En este caso, Barbero emite esos signos sociales por medio de sus soliloquios en los que claramente denota y deja por sobrentendido al lector/audiencia que su modelo de actuación de la vida social no encaja con el nuevo modelo que desvaloriza la función social de un teatro con ideologías comerciales y desechan el valor verdadero del lenguaje.

En ambas obras, la reconstrucción del pasado, de su regreso, muestra un dolor común ausentado de la historia oficial. Esto se percibe ya sea por medio del recuerdo de los personajes trágicos representados por Barbero en Latinoamérica o por los sueños de Balbuena en el que aparecen "hombres sin rostro o con la misma cara. Hombres rezando y blasfemando al mismo tiempo...comíamos mierda, bebíamos agua podrida. Y yo seguía ciego...con sus propias tripas en la mano que no paraba de correr" (Canción de cuna

$20 \quad$ Esta es una manera artística de visibilizar la ausencia. Ver "Presence and Absence (On Art and Disappearance)", en Michael Lazzara, Chile in Transition: The Poetics and Politics of Memory (2006), pp.101-128. 
para un anarquista 258). Rosaura, por su parte, acepta el recuerdo en el que la golpiza de Epifanio provoca su aborto. Estas historias ausentes de la memoria colectiva en un momento posdictatorial se convierten en presencia al momento de su enunciación, de su reconstrucción y concientización. Es entonces cuando los personajes pueden cobrar cierto sentido de la realidad. El dolor de la ausencia, de la invisibilidad, de la pérdida de sus raíces, se visibiliza en un presente, aunque distorsionado. Sin embargo, esta misma distorsión devela el sufrimiento del desarraigo. Su estado emocional, en tanto inestable, se presenta en forma de una "locura" que razona lo irrazonable ${ }^{21}$. Rosaura dialoga con los objetos que causan su trauma, mientras que Balbuena vive bajo el estigma de haber estado en un hospital psiquiátrico. Los discursos o "disparates" de Balbuena son precisamente las verdades que Rosaura había optado por desechar. Por su parte, en la obra de López Mozo, Alvar describe a Barbero como un viejo loco que se fue con el rabo entre las piernas. Aquí, el regreso de un viejo loco (Barbero) desata el verdadero trauma de Alvar, cuya ironía expone que su padre también se exilia a Latinoamérica, pero nunca vuelve. Esta locura, producto del desarraigo, es una forma alternativa de confrontar y volver en presencia la historia de los exiliados. Así, la locura provoca la aceptación de la realidad pasada y de alguna manera los personajes se liberan. No obstante, para los protagonistas, esta liberación, sinónimo de muerte, es la única salida viable para ellos.

Las historias de los personajes en Canción de cuna para un anarquista y El olvido está lleno de memoria representan una de las realidades de muchos que viven y vivieron en el exilio, forzados por motivos políticos. Asimismo, demuestran que el desarraigo no es simplemente la separación de algo, sino además es la pérdida total de ese algo. Por medio del análisis de las obras de Díaz y López Mozo, vemos una de las fallas en los procesos de la transición a la democracia, la cual radica en las políticas del olvido. Ambos autores ven la necesidad de retomar esta cuestión a principios del siglo XXI como manifestación de un problema aún no resuelto. Asimismo, contrastan dos épocas, en teoría distintas, que siguen generando una sensación de abandono y rechazo. Mientras España es el catalizador del desarraigo y el olvido en

21 En cuanto a la función de la locura, ver History Beyond Trauma (2004) de Davoine y Gaudillière. Su estudio se encarga de analizar lo que la locura tiene que decir, "for the madness that speaks to itself -or to everyone, that is, to no one- shows outside of temporality, what no one wants to know anything about and what is not inscribed as past" (9). 
las obras, Chile se presenta como un cementerio simbólicamente fantasmal. Este espacio posdictadura, precario y aislado, ya no simboliza aquel lugar añorado por Barbero en el que fue bien recibido y logra lo que no pudo en España. A través de estos discursos alternativos de los exiliados, este estudio ha problematizado la idea del regreso físico y del regreso simbólico de la memoria como formas de restablecimiento. Al contrario, el regreso al origen del evento traumático se convierte en un retroceso que engendra una nueva herida y/o activa el trauma pasado por primera vez. Dichas características temáticas, las estrategias dramáticas de experimentación y los contextos sociopolíticos nos permiten seguir hablando de una dramaturgia posmoderna transatlántica, tal como lo prueban aquí las obras de Díaz y López Mozo. Tanto el teatro posdictadura español como el del Cono Sur confrontan sociedades fragmentadas que, por medio de la escena y del texto, se dan a la tarea de convertir en presencias las ausencias.

\section{BIBLIOGRAFÍA}

Alted, Alicia. "Identidad y memoria en el exilio." La voz de los vencidos. Madrid: Aguilar, 2005. 391- 427.

Aznar Soler, Manuel. "El exilio teatral republicano de 1939." Seminario de literatura española contemporánea. Alicante: Biblioteca Virtual Miguel de Cervantes. Recuperado de: www. cervantesvirtual.com/nd/ark:/59851/bmcdf6p8. Revisado en 2002.

Barrera, Trinidad. "El exilio español y su influjo en el teatro latinoamericano." Las puertas del drama 3 (2000): 44-49.

Binns, Niall. Argentina y la guerra civil española. Barcelona: Calambur, 2012.

Chile y la guerra civil española. Barcelona: Calambur, 2013.

Uruguay y la guerra civil española. Barcelona: Calambur, 2016.

Burgos, Nidia. "Para una cartografía teatral del exilio." Stichomythia 11/12 (2011): 42-49.

Camus, Albert. "The Absurd Man.” The Myth of Sisyphus: And Other Essays. 1942. Trad. Justin O’Brien. New York: Vintage International, 1991. 65-92.

Caruth, Cathy. Unclaimed Experience: Trauma, Narrative and History. Maryland: John Hopkins University Press, 1996.

Davoine, Françoise, y Jean-Max Gaudillière. History Beyond Trauma. Trad. Susan Fairfield. New York: Other Press, 2004.

Díaz, Jorge. Antología de la perplejidad. Santiago de Chile: Edebé, 2003.

Dubatti, Jorge. "Por qué hablamos de Postdictadura 1983-2008". La revista del CCC. 2/4 (2008): 14-20. 
Féral, Josette. "Every Transaction Conjures a New Boundary." Critical Theory and Performance. Ed. Janelle G. Reinelt y Joseph R. Roach. Michigan: U. of Michigan Press, 2007. 49-66.

Foster, Hal. “(Post)Modern Polemics.” Recordings: Art, Spectacle, Cultural Politics. Washington: Bay Press, 1985. 121-138.

Gabriele, John P. "Metateatro y mnemotécnica: convenciones posmodernistas en El olvido está lleno de memoria de Jerónimo López Mozo.” Alpha 25 (2007): 101-114.

Hutcheon, Linda. A Poetic of Postmodernism. New York: Routledge, 1988.

Lazzara, Michael J. "Presence and Absence (On Art and Disappearance)." Chile in Transition: The Poetics and Politics of Memory. Florida: University Press of Florida, 2006. 101-128

Leonard, Candyce y John P. Gabriele. "Memoria teatralizada/vida rememorada." Teatro español del siglo XXI: actos de memoria. North Carolina: Editorial Teatro, 2008. 1-6.

López Mozo, Jerónimo. El olvido está lleno de memoria. Teatro español del siglo XXI: actos de memoria. Ed. Candyce Leonard y John P. Gabriele. North Carolina: Editorial Teatro, 2008 [2002]. 133-190.

"El teatro español ante el siglo XXI.” Monteagudo 11 (2006): 41-54. "La búsqueda del despojamiento." RESAD 6 (2001): 1-17.

Lyotard, Jean-François. The Postmodern Condition: A Report on Knowledge. Trad. Geoff Bennington y Brian Massumi. Minneapolis: University of Minnesota Press, 1979.

Malkin, R. Jeanette. Memory-Theater and Postmodern Drama. Michigan: U. of Michigan Press, 2002.

Moulian, Tomás. Chile Actual: anatomía de un mito. 1997. Santiago: LOM, 2002.

Naficy, Hamid. "Framing Exile: From Homeland to Homepage." Home, Exile, Homeland. New York: Routledge, 1999. 1-13.

Rizk, J. Beatriz. Posmodernismo y teatro en America Latina: Teorías y prácticas en el umbral del siglo XXI. Madrid: Iberoamericana, 2001.

Said, Edward. "Reflections on Exile." Reflections on Exile and Other Essays. Massachusetts: Harvard University Press, 2000. 173-186.

Silva, Emilio. Las fosas de Franco. Madrid: Temas de Hoy, 2005.

Trancón, Santiago. Teoría del teatro. Madrid: Fundamentos, 2006.

Woodyard, George. "Jorge Díaz, y el teatro chileno desde la otra orilla." Resistencia y poder: Teatro en Chile. Ed. Heidrun Adler y George Woodyard. Madrid: Iberoamericana, 2000. $75-88$. 